\title{
IMPLEMENTATION OF THE WORKPLACE PARKING LEVY AS A TRANSPORT POLICY INSTRUMENT
}

\begin{abstract}
Car parking spaces occupy significant areas land within cities and, in many areas, is often provided to motorists free of charge or at low cost. This can encourage car use which leads to traffic congestion and environmental degradation. In response, local authorities have increasingly used parking policies to address these issues. However, the effectiveness of these interventions have been limited by a lack of control over private non-residential parking spaces, including those provided by workplaces. In 2000 the UK Government enacted legislation which enabled local authorities in England to charge employers for the parking they provided for staff via a Workplace Parking Levy (WPL). Whilst this was expected to act as a catalyst for the introduction of other similar schemes throughout the UK, only one authority has introduced a WPL to date.
\end{abstract}

This paper draws on the results of a national survey of local politicians and transport officers to ascertain the views of policy makers in the UK regarding transport-related issues, and the effectiveness and acceptability of various measures to reduce congestion, specifically the WPL. It explores the reasons why local authorities may consider introducing a WPL, examines issues with respect to the principle of the scheme, and discusses pre- and post-implementation concerns. The final section considers the likelihood of future schemes being introduced. It concludes that whilst there are a number of issues associated with WPL implementation, not least its perceived effectiveness and acceptability, further schemes can be expected in the UK in future. 


\section{INTRODUCTION AND LITERATURE REVIEW}

Car parking is an important and complex feature of the transport system, not least because motor vehicles are parked for a significant proportion of their life. The RAC Foundation (RAC 2012) reported that cars are parked $96 \%$ of the time which makes parking a major component of car use. A US estimate suggests that for the 240 million passenger vehicles and 10 million on-road freight vehicles, the number of parking spaces is anything between 722 and 2,100 million spaces (Chester et al 2011), whilst Shoup (2005) notes that 'parking is the single biggest land use in cities'. This land use carries a significant cost, but in practice it is often not paid for by the user which can therefore encourage additional car use and lead to congestion. This is because 'free' parking can make motoring appear more attractive than it would be if it were priced to meet the full economic cost of providing the space. Moreover, parking is also a direct cause of congestion as motorists may be obliged to search for an available parking space after they have arrived at their destination. In addition, the extra car use induced by under-priced parking can be linked to poor air quality - car traffic accounts for $13.4 \%$ of the total $\mathrm{UK} \mathrm{CO}_{2}$ emissions (SMMT 2014) - whilst other negative environmental impacts associated with parking include storm water runoff, loss of habitat, water pollution, flooding, heat islands as well as noise pollution from vehicles stopping and starting (Forinash et al 2004).

Due to the issues associated with land use, congestion and the environment, local authorities can deliver significant benefits by introducing parking levies and related policies. First, "well designed parking policies, in various ways, contribute to the promotion of a more efficient use of the transport network, lower emissions, higher densities and better, more inclusive urban design” (Marsden 2006). Second, due to the link between parking and car use, parking policies "can be a useful instrument in managing travel demand and addressing congestion in crowded downtowns" (Qian 2011). Third, charging motorists and "using curb-parking revenue to pay for local public services is much fairer than keeping curb parking free, losing the revenue needed to pay for public services, creating chaotic parking problems on busy streets, and increasing traffic congestion caused by drivers who are searching for free parking” (Pierce and Shoup 2013). However, local authorities can only use parking policies to achieve their policy objectives where they are able to exert some form of control, yet local authorities only have the power to change the price or quantity of public parking provision and have relatively little influence over (the often significant proportion of) privately owned parking, which tends to reduce the effectiveness of parking strategies.

Private parking can include private residential parking such as a driveway or garage at the home, and private non-residential (PNR) parking which encompasses car parks in urban centres which are available to the general public as well as spaces at the workplace for employees. The problems caused by this lack of control are emphasised due to the fact that "private nonresidential parking typically forms half or more of the total stock in town centres" (IHT 2005). Specifically, parking at the workplace is of particular concern. As stated, "the availability of convenient, guaranteed, free or cheap parking is a major factor in influencing people's decisions to drive to work" (HMSO 1996), with free workplace parking highlighted as a major contributor to peak period congestion due to the influence of free parking on car use as well as the tidal demand of entering an urban area in the morning and leaving in the evening, which typically revolves around the '9-5 work day' (Hill 2005). While the control on parking is not the only option open to policy makers, there being other approaches such as carpooling (see Vanoutrive et al 2012), it is an important measure to consider when seeking to address the issue of congestion and environmental degradation. 
To address the issue of workplace parking, the UK Government gave local authorities power to introduce a Workplace Parking Levy (WPL) in the Transport Act (2000). This allowed authorities to charge employers for the parking provided for their staff, with all the revenue hypothecated to improving local transport. According to the White Paper (preceding the Act), the reasons local authorities might adopt a WPL could be "to reduce the amount of parking available as a means of reducing car journeys and increasing use of public transport, walking and cycling” (DETR 1998). Local authorities also received the power to introduce a Road User Charge (RUC) in the Transport Act 2000. The power to introduce a WPL, however, was legislated in order "to accommodate local authorities who wished to control demand for road travel to city centres but who had indicated, during the consultation processes, that they did not consider road user charging to be an appropriate solution for their locality" (Bonsall and Milne 2003). This was justified on the basis that what is appropriate for London is not necessarily suitable for smaller cities and a weaker demand management measure may be more appropriate (Burchell et al. 2015). Following the introduction of the Transport Act 2000, interest from 35 local authorities (in both the WPL and RUC) meant there was an assumption by the UK government that there would be a number of "workplace parking schemes [introduced] over the next decade” (DETR 2000). Twenty years later however, only one WPL has been introduced in the UK in the city of Nottingham.

One of the main reasons for this relates to the lack of acceptance of a price-based approach to the problem. Many studies including Jones (1991), Ison (2000), Thorpe et al. (2000), Ison and Wall (2002) and Schade and Schlag (2003) have focused on this issue specifically in the area of road pricing. Jones (1991) surveyed public attitudes to UK traffic problems in urban areas and potential approaches to addressing them. Whilst somewhat dated, Jones revealed in a poll of polls of various national and London-based surveys that the measure backed most strongly by the public was for the provision of alternatives to car use, namely the improvement in public transport, Park and Ride schemes, and the encouragement of cycling and walking. Urban road pricing on the other hand was only supported by a minority and was seen as being a 'policy of last resort'. Jones (1998) returned to this point stating that the lack of public support for road user charging could be argued on the grounds that 'Traffic containment or reduction is needed, but it could be better or more appropriately achieved in other ways. Either by simply improving modal alternatives (for example 'better public transport') or through the use of other restraint measures such as bans on road traffic in major shopping streets, or restrictions on access to certain parts of the road network. Something less 'draconian' will suffice'. Similarly, 25 years ago Higgins stated that road pricing is only likely to succeed in conditions of severe congestion (Higgins 1994). This is the line supported by Jones (1998) in that the lack of need for road pricing is argued on the basis that 'road traffic conditions are not bad enough to warrant the use of such an extreme measure, people would rather put up with the delays.'

The aim of this paper is to ascertain the views of policy makers in the UK with respect to the WPL in order to understand their concerns surrounding such a scheme and to determine the likelihood of a WPL scheme being adopted elsewhere, both within the UK and internationally. Specifically, it seeks to understand the views pertaining to transport related issues as well as the effectiveness and acceptability of various measures to reduce congestion. It then explores the reasons why local authorities might introduce a WPL, issues with respect to the principle of the scheme, and pre and post-implementation concerns. The final section considers the future of the WPL as a policy measure in the UK, in terms of the number of future schemes and the degree and type of support required should additional localities choose to pursue this.

\section{PARKING LEVIES}


Parking levies are a charge on a specific type of parking in a city. Such levies can apply to a whole area or to specific zones, while different schemes have been introduced to cover different categories of parking - from all workplace parking, to all private non-residential parking, or to all parking spaces within a cordon. To date, parking levies have been introduced in Singapore (1975-1998), Australia (in Sydney (1992), Perth (1999), Melbourne (2007) and Adelaide (2014)) and in the UK (Nottingham (2012)). Parking levies have previously been introduced to manage congestion, encourage public transport use, regenerate the area, provide revenue to subsidise and fund public transport investment, improve air quality and encourage (shoppers/visitors) or discourage (commuters) certain type of users (Burchell et al. 2015, Enoch and Ison 2005, Transport for New South Wales 2013 and Hamer et al 2011). Typically, all or a portion, of the revenue is hypothecated to be invested into local transport and is seen as an important factor to ensure that parking levies are effective in meeting their goals.

In the UK, Nottingham City Council (NCC) introduced a WPL in April 2012 and was primarily introduced to raise revenue to improve local transport. However, the Nottingham WPL is also anticipated to regenerate the area, improve land use, deliver environmental improvements, support businesses in developing travel plans, in addition to exerting a direct and indirect impact on traffic congestion (Burchell et al 2015).

Dale et al (2017) provide evidence of congestion constraint due to the WPL with the analysis showing that the number of liable workplace parking places is positively related to delay. The study included a number of exogenous variables known to impact congestion including road work activity and economic activity measured by the number of people of working age not claiming out of work benefits both of which also proved statistically significant. Dale et al conclude that while the WPL does result in congestion constraint this impact is being masked by economic growth and temporarily by road work activity associated with the implementation of the major transport improvements part funded by the WPL. The scale of the WPL effect is quoted as 15 seconds of time saving per vehicle mile in 2013 or 1,146 days. While Dale et al do not comment on whether this effect is significant in the broader sense it would seem that this congestion constraint makes an important contribution as a TDM measure even though other exogenous factors may have impact.

\section{METHOD}

Between October 2013-February 2014, one Councillor (an elected official) and one Officer (those who manage the implementation and operation of a policy) responsible for transport in each UK local authority that was eligible to implement a WPL were contacted by email to ask if they would be willing to complete a short internet-based survey. The survey population comprised all English County (rural), Unitary (both rural and urban), Metropolitan (large urban), and London Borough (comprising the 32 Districts of London) Councils ${ }^{1}$. In the case of Metropolitan areas (such as those based in Manchester and Birmingham), transport is usually overseen by an overarching Transport Authority which is responsible for a cohesive transport strategy for its constituent Boroughs. In these cases, the views of both the overarching Transport Authority and the individual Metropolitan Boroughs were collected, for although the

\footnotetext{
${ }^{1}$ See www.politics.co.uk/reference/local-government-structure for more details of the local Government structure in England
} 
decision to introduce a WPL is ultimately the responsibility of the Transport Authority, it is also possible that a WPL could be introduced within a single Borough.

In total 156 authorities, excluding Nottingham City Council (NCC) were contacted by email. Contact details were obtained from the Municipal Year Book (2013). Owing to the number of respondents [312], a web-based survey was developed with the aim of enhancing the response rate and giving respondents the option to remain anonymous (which was important due to the political nature of the WPL). Such anonymity can be more difficult to achieve with email surveys, hence why the web-based approach was adopted (Bryman 2004). Table 1 details the authorities who were contacted.

Table 1. Transport Authorities in England

\begin{tabular}{lc}
\hline \multicolumn{1}{c}{ Type } & Number of Councils \\
\hline Unitary Authority & 55 \\
County Councils (Two-tier) & 27 \\
Integrated Transport Authority (Metropolitan & 6 \\
Borough) & 36 \\
Districts of Metropolitan Boroughs & 32 \\
London Boroughs & 1 \\
City of London & 157 \\
Total & \\
\hline
\end{tabular}

The full population was surveyed which meant the views of 156 out of the 157 authorities (excluding NCC) were sought. For each of the 156 authorities, one transport Officer and one transport Councillor were contacted; thus 312 surveys were distributed. All non-respondents were contacted one and two months after the initial contact with the aim of boosting the response rate. In total 133 responses were received (a 43\% response rate). The split was fairly even between Councillors and Officers as well as by the different type of authorities although 27 respondents chose to remain anonymous. Figure 1 provides a detailed breakdown of the responses by job role and local authority type. 
Figure 1. Type of authority and role of respondents



Base: 106 respondents

In order to obtain the opinions of the various respondents, a self-completion questionnaire was used because it was cheaper to administer than face-to-face interviews (particularly given that the sample was spread geographically); was quicker than face-to-face and telephone interviews; and could be completed anonymously (Bryman, 2004). The web-based questionnaire was developed using Bristol Online Survey (Bristol Online, 2013). The survey was piloted with Officers and Councillors from NCC with a good working knowledge of the WPL. The respondents were asked to complete the survey from a local authority perspective and this provided useful feedback. The majority of questions were of a 5-point Likert scale format ranging from strongly disagree to strongly agree, very unconcerned to very concerned and very unacceptable to very acceptable.

The survey was based on the approach developed by Ison (2000) and Ison and Wall (2002). These together with a wider review of the relevant literature informed the questions. The survey is provided in the Appendix in the format it appeared on the webpage detailing the frame in terms of the effectiveness and acceptance of TDM measures and role played by the WPL in addressing congestion and related issues.

\section{FINDINGS}

This section is divided into a number of sections, namely: the perception of the respondents to the seriousness of transport related issues, the effectiveness and acceptance of measures used to address traffic-related congestion, including the WPL and the issues/concerns surrounding the implementation of the WPL.

The seriousness of transport related issues

First, respondents were asked about the severity of transport issues. Wear and tear of the road network was identified as being the greatest concern with $60 \%$ of respondents stating that this was a serious or very serious issue. This was followed by 'morning congestion' (45\% considered it to be serious/very serious), 'evening congestion' (44\%), 'air pollution' (36\%), 'social exclusion' (31\%) and 'noise pollution' (21\%). Although fewer than half of the respondents stated that congestion was serious or very serious, under $10 \%$ of the respondents 
from County Councils, Metropolitan Councils and London Boroughs stated congestion was not at all or not very serious.

In addition, the respondents were also segmented into different groups to identify variations in their views. Specifically this included Councillors and Officers at the Unitary, County, Metropolitan and London Borough level. The key findings were:

- The more rural the authority, the more serious the wear and tear issue was considered to be. Hence County Councils viewed it as the most significant issue (75\%) and London Boroughs the least (29\%).

- Nearly two-thirds of the respondents from London Boroughs viewed congestion to be serious or very serious (67\% evening/62\% morning); the highest amongst the groups.

- London Boroughs and Metropolitan areas (i.e. the most urbanised) viewed problems associated with air, and noise pollution caused by transport and social exclusion as being more of an issue than Unitary and County Councils. Indeed, the single biggest issue for London Borough respondents was the severity of air pollution (82\% serious or very serious).

- Councillors perceived congestion, air pollution and noise pollution to be slightly more of an issue compared with Officers who perceive wear and tear of the road network to be more of a concern.

The findings are summarised in Figure 2:

Figure 2. Type of authority: Transport related issues

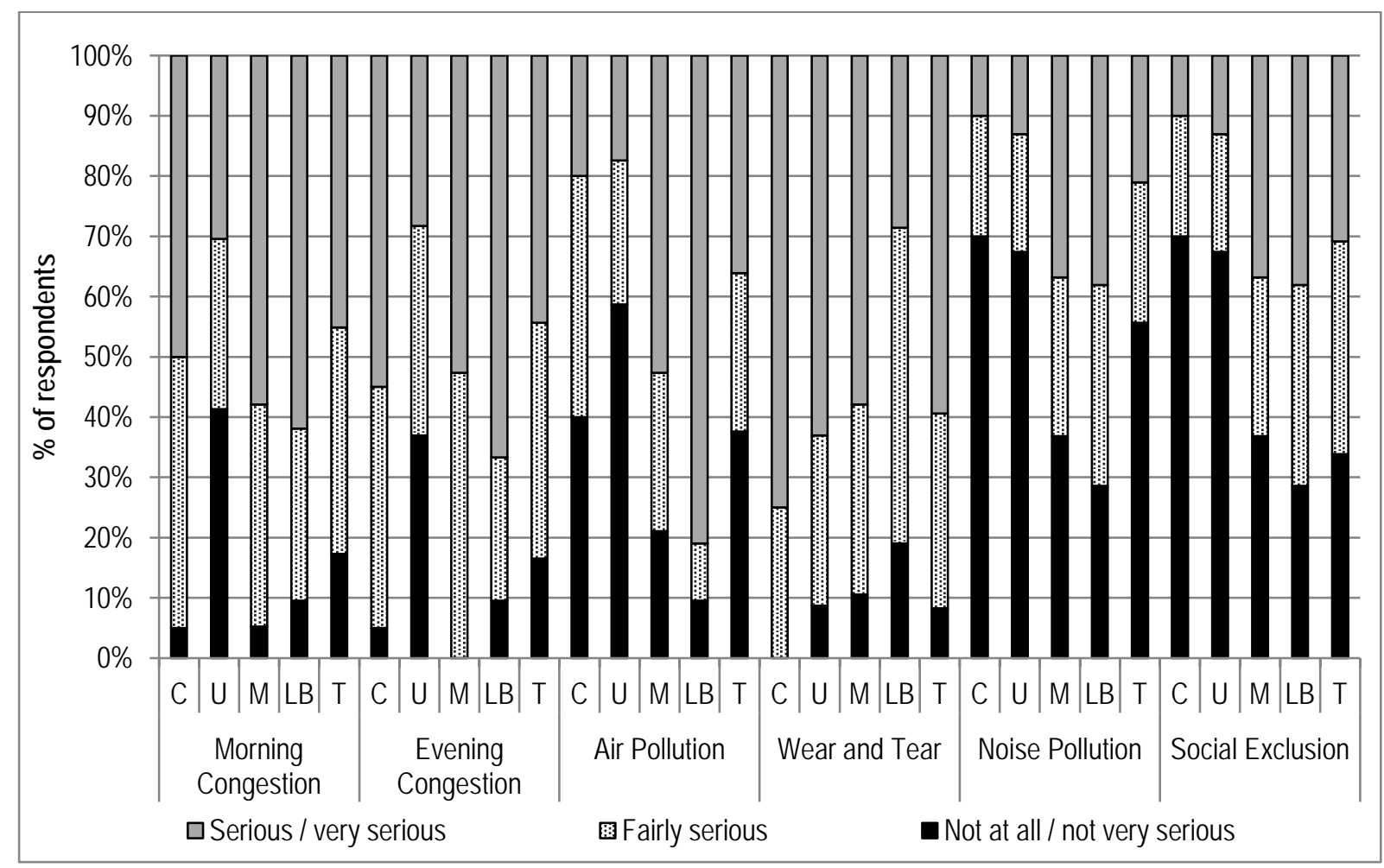

Base: 133 responses

Note: County (C), Unitary (U), Metropolitan (M), London Borough (LB) and Total (T) which presents the average response from all the respondents. 
Effectiveness of policy options for reducing congestion

In terms of reducing congestion, the responses concerning the effectiveness and acceptability of the various policy options was on a 5 -point Likert scale with ' 1 ' representing 'very ineffective/unacceptable' and ' 5 ' 'very effective/acceptable'. Table 2 presents the findings with respect to the policy options of the different types of authority. 
Table 2. Type of authority: Effectiveness of policy measures for addressing congestion (\% of respondents)

\begin{tabular}{|c|c|c|c|c|c|c|c|}
\hline Policy Measure & Response & $\begin{array}{l}\text { Count } \\
\text { y (\%) }\end{array}$ & $\begin{array}{l}\text { Unitary } \\
(\%)\end{array}$ & $\begin{array}{c}\text { Metropolitan } \\
(\%)\end{array}$ & $\begin{array}{l}\text { London } \\
\text { Borough } \\
(\%)\end{array}$ & $\begin{array}{c}\text { Total } \\
\text { Response } \\
\mathbf{s}\end{array}$ & $\begin{array}{c}\text { Mean } \\
\text { Scor } \\
\text { e }\end{array}$ \\
\hline \multirow{2}{*}{$\begin{array}{l}\text { Frequency and } \\
\text { Reliability PT }\end{array}$} & Effective / Very Effective & 80 & 78 & 89 & 100 & 83 & \multirow{2}{*}{4.11} \\
\hline & Ineffective / Very Ineffective & 10 & 4 & 5 & 0 & 5 & \\
\hline \multirow{2}{*}{$\begin{array}{l}\text { Reduce cost of } \\
\text { PT }\end{array}$} & Effective / Very Effective & 70 & 78 & 79 & 100 & 77 & \multirow{2}{*}{4.03} \\
\hline & Ineffective / Very Ineffective & 10 & 7 & 5 & 0 & 8 & \\
\hline \multirow{2}{*}{$\begin{array}{l}\text { Improve Local } \\
\text { Railway }\end{array}$} & Effective / Very Effective & 75 & 65 & 89 & 76 & 72 & \multirow{2}{*}{3.92} \\
\hline & Ineffective / Very Ineffective & 15 & 11 & 11 & 10 & 11 & \\
\hline \multirow{2}{*}{$\begin{array}{l}\text { Improve } \\
\text { Cycling and } \\
\text { Walking }\end{array}$} & Effective / Very Effective & 50 & 72 & 68 & 90 & 68 & \multirow{2}{*}{3.68} \\
\hline & Ineffective / Very Ineffective & 30 & 11 & 16 & 0 & 14 & \\
\hline \multirow{2}{*}{ Home Working } & Effective / Very Effective & 40 & 63 & 47 & 81 & 59 & \multirow{2}{*}{3.58} \\
\hline & Ineffective / Very Ineffective & 5 & 13 & 11 & 10 & 11 & \\
\hline \multirow{2}{*}{ Introduce RUC } & Effective / Very Effective & 65 & 54 & 47 & 86 & 60 & \multirow{2}{*}{3.53} \\
\hline & Ineffective / Very Ineffective & 15 & 22 & 26 & 14 & 21 & \\
\hline \multirow{2}{*}{ Park and Ride } & Effective / Very Effective & 70 & 63 & 84 & 33 & 65 & \multirow{2}{*}{3.51} \\
\hline & Ineffective / Very Ineffective & 10 & 15 & 11 & 33 & 17 & \\
\hline \multirow{2}{*}{$\begin{array}{l}\text { Road } \\
\text { Expansion }\end{array}$} & Effective / Very Effective & 65 & 63 & 68 & 29 & 59 & \multirow{2}{*}{3.47} \\
\hline & Ineffective / Very Ineffective & 15 & 17 & 11 & 43 & 19 & \\
\hline \multirow{2}{*}{ Car sharing } & Effective / Very Effective & 55 & 48 & 37 & 57 & 52 & \multirow{2}{*}{3.38} \\
\hline & Ineffective / Very Ineffective & 20 & 20 & 21 & 19 & 19 & \\
\hline \multirow{2}{*}{$\begin{array}{l}\text { Increase } \\
\text { parking } \\
\text { charges }\end{array}$} & Effective / Very Effective & 55 & 50 & 42 & 52 & 48 & \multirow{2}{*}{3.30} \\
\hline & Ineffective / Very Ineffective & 15 & 26 & 26 & 24 & 24 & \\
\hline \multirow{2}{*}{$\begin{array}{l}\text { Reduce } \\
\text { Supply } \\
\text { Parking }\end{array}$} & Effective / Very Effective & 55 & 30 & 53 & 62 & 44 & \multirow{2}{*}{3.20} \\
\hline & Ineffective / Very Ineffective & 30 & 41 & 37 & 24 & 32 & \\
\hline \multirow{2}{*}{ Introduce WPL } & Effective / Very Effective & 40 & 33 & 42 & 67 & 40 & \multirow{2}{*}{3.17} \\
\hline & Ineffective / Very Ineffective & 40 & 33 & 26 & 14 & 27 & \\
\hline
\end{tabular}

Base: 133 responses (Mean value $-5=$ very effective and 1 = very ineffective)

NB. Percentages may not add up to 100 owing to rounding

The measures seen to be the most effective in reducing congestion were policies linked to the attractiveness of public transport, cycling and walking. This included 'improving public transport by reducing the passenger cost' as well as 'more frequent and reliable services'; 
'improving local railway services'; and 'improving cycling and pedestrian routes'. The least effective schemes were all parking related and included the introduction of a 'WPL'; 'reduction in parking supply'; and an 'increase in parking charges' - incidentally the 'WPL' was deemed the least effective measure for dealing with congestion out of the policy options provided. However, this view was not uniform, and respondents from London Boroughs viewed parking policies (and 'WPL' in particular) to be more effective than other measures. Respondents from London Boroughs also stated that 'park and ride' and 'expanding the road network' were ineffective measures for reducing congestion, whereas the other types of authorities tended to view these policies as effective.

In addition, the more urban the authority the more effective a reduction in the cost of public transport was perceived to be in addressing congestion, whilst Metropolitan areas viewed a 'RUC' as the least effective measure for reducing congestion compared with the other types of authority. Also interesting is that Officers tended to view pricing measures such as a 'RUC', 'WPL' and 'increased parking charges' as well as the 'expansion of the road network' as more effective than Councillors.

\section{Acceptability of policy options for reducing congestion}

Similar to the effectiveness of the policies, the most acceptable measures were policies that were perceived to deliver improvements; these included 'reducing the cost of public transport', 'improving the frequency and reliability of public transport', 'improving local railway services' as well as an 'improvement in cycling and walking routes'. The one policy with a major discrepancy relating to effectiveness and acceptability was 'RUC'. $60 \%$ of the respondents thought it was effective at reducing congestion but only 14\% thought it acceptable. Other policies deemed unacceptable were associated with a 'reduction in the availability of parking' as well as an additional motoring cost such as 'increasing parking charges' or a 'WPL'. Table 3 presents the responses with respect to acceptability. 
Table 3. Type of authority: Acceptability of policy measures for addressing congestion (\% of respondents)

\begin{tabular}{|c|c|c|c|c|c|c|c|}
\hline Policy Measure & Response & County & Unitary & Metropolitan & $\begin{array}{l}\text { London } \\
\text { Borough }\end{array}$ & Total & $\begin{array}{l}\text { Mean } \\
\text { Value }\end{array}$ \\
\hline \multirow{2}{*}{$\begin{array}{l}\text { Frequency and } \\
\text { Reliability PT }\end{array}$} & Acceptable / Very Acceptable & 90 & 96 & 95 & 100 & 94 & \multirow{2}{*}{4.55} \\
\hline & Unacceptable / Very Unacceptable & 0 & 4 & 0 & 0 & 3 & \\
\hline \multirow{2}{*}{$\begin{array}{l}\text { Improve Local } \\
\text { Railway }\end{array}$} & Acceptable / Very Acceptable & 90 & 89 & 95 & 100 & 92 & \multirow{2}{*}{4.53} \\
\hline & Unacceptable / Very Unacceptable & 5 & 0 & 0 & 0 & 2 & \\
\hline \multirow{2}{*}{$\begin{array}{l}\text { Reduce cost of } \\
\text { PT }\end{array}$} & Acceptable / Very Acceptable & 90 & 93 & 95 & 95 & 93 & \multirow{2}{*}{4.50} \\
\hline & Unacceptable / Very Unacceptable & 10 & 4 & 0 & 0 & 4 & \\
\hline \multirow{2}{*}{$\begin{array}{l}\text { Improve Cycling } \\
\text { and Walking }\end{array}$} & Acceptable / Very Acceptable & 85 & 89 & 74 & 90 & 86 & \multirow{2}{*}{4.17} \\
\hline & Unacceptable / Very Unacceptable & 0 & 2 & 5 & 0 & 2 & \\
\hline \multirow{2}{*}{ Home Working } & Acceptable / Very Acceptable & 70 & 89 & 68 & 86 & 81 & \multirow{2}{*}{4.08} \\
\hline & Unacceptable / Very Unacceptable & 0 & 0 & 0 & 10 & 2 & \\
\hline \multirow{2}{*}{ Park and Ride } & Acceptable / Very Acceptable & 85 & 76 & 84 & 43 & 74 & \multirow{2}{*}{3.98} \\
\hline & Unacceptable / Very Unacceptable & 0 & 0 & 5 & 14 & 3 & \\
\hline \multirow{2}{*}{ Car sharing } & Acceptable / Very Acceptable & 70 & 76 & 68 & 76 & 74 & \multirow{2}{*}{3.91} \\
\hline & Unacceptable / Very Unacceptable & 0 & 7 & 0 & 5 & 3 & \\
\hline \multirow{2}{*}{$\begin{array}{l}\text { Road } \\
\text { Expansion }\end{array}$} & Acceptable / Very Acceptable & 80 & 80 & 68 & 38 & 70 & \multirow[t]{2}{*}{3.69} \\
\hline & Unacceptable / Very Unacceptable & 15 & 11 & 11 & 24 & 13 & \\
\hline \multirow{2}{*}{$\begin{array}{l}\text { Increase } \\
\text { parking charges }\end{array}$} & Acceptable / Very Acceptable & 25 & 15 & 26 & 29 & 21 & \multirow{2}{*}{2.39} \\
\hline & Unacceptable / Very Unacceptable & 60 & 74 & 53 & 38 & 61 & \\
\hline \multirow{2}{*}{$\begin{array}{l}\text { Reduce Supply } \\
\text { Parking }\end{array}$} & Acceptable / Very Acceptable & 15 & 9 & 11 & 33 & 14 & \multirow{2}{*}{2.19} \\
\hline & Unacceptable / Very Unacceptable & 70 & 74 & 63 & 43 & 66 & \\
\hline \multirow{2}{*}{ Introduce WPL } & Acceptable / Very Acceptable & 25 & 11 & 11 & 29 & 16 & \multirow{2}{*}{2.16} \\
\hline & Unacceptable / Very Unacceptable & 65 & 80 & 74 & 38 & 67 & \\
\hline \multirow{2}{*}{ Introduce RUC } & Acceptable / Very Acceptable & 10 & 11 & 5 & 43 & 14 & \multirow{2}{*}{1.86} \\
\hline & Unacceptable / Very Unacceptable & 85 & 87 & 84 & 33 & 78 & \\
\hline
\end{tabular}

Base: 133 responses (Mean value $-5=$ very acceptable and 1 = very unacceptable)

NB. Percentages may not add up to 100 owing to rounding

Moreover, the more rural the type of authority, the more acceptable the 'expansion of the road network' was viewed. Urban authorities, particularly London Boroughs on the other hand, viewed 'road expansion' as an unacceptable way to reduce congestion. Once more, the opinions of London Boroughs differed most in comparison to other authorities. In terms of 
London Boroughs RUC and WPL were deemed more acceptable and policies such as 'park and ride' and 'expanding the road network' were much less acceptable. This is perhaps not too surprising. The least acceptable measure for an individual type of authority was the introduction of an 'RUC' in a Metropolitan area. Councillors believe introducing a 'WPL', a 'RUC' as well as 'increasing parking charges', are more acceptable in comparison to the views of Officers. Despite this, the majority of both groups view these approaches to be an unacceptable approach to tackling congestion. Instead, Officers viewed the softer policy interventions as more acceptable; these include 'improving cycling and walking', 'car sharing' and 'home working'.

In summary, the 'WPL' is viewed by Councillors and Officers as less effective, compared to other measures, especially those that enhance transport provision and unacceptable for reducing congestion, though not by everyone. The following findings cover the views of the respondents with respect to the WPL.

Reasons for a WPL

As stated in section 3 one of the prime reasons for the introduction of the WPL in the city of Nottingham was to raise revenue in order to improve local transport provision as part of a package of measures which would lead to a reduction in congestion, an environmental improvement as well as improved land use and urban regeneration. Table 4 provides the views of local authorities with respect to why a WPL might be introduced.

Table 4. Type of Authority: Reason for introducing a WPL (\% of respondents)

\begin{tabular}{|c|c|c|c|c|c|c|c|}
\hline & & County & Unitary & Metropolitan & $\begin{array}{l}\text { London } \\
\text { Borough }\end{array}$ & Total & $\begin{array}{l}\text { Mean } \\
\text { Value }\end{array}$ \\
\hline \multirow{3}{*}{$\begin{array}{l}\text { Reduce } \\
\text { Congestion }\end{array}$} & Strongly agree / Agree & 70 & 61 & 63 & 62 & 61 & \multirow{3}{*}{3.56} \\
\hline & Neither agree nor disagree & 25 & 28 & 5 & 19 & 24 & \\
\hline & Strongly disagree / Disagree & 5 & 11 & 32 & 19 & 15 & \\
\hline \multirow{3}{*}{ Raise Revenue } & Strongly agree / Agree & 55 & 57 & 47 & 57 & 53 & \multirow{3}{*}{3.45} \\
\hline & Neither agree nor disagree & 40 & 26 & 32 & 29 & 32 & \\
\hline & Strongly disagree / Disagree & 5 & 17 & 21 & 14 & 15 & \\
\hline \multirow{3}{*}{$\begin{array}{l}\text { Environmental } \\
\text { Benefit }\end{array}$} & Strongly agree / Agree & 40 & 52 & 63 & 71 & 51 & \multirow{3}{*}{3.38} \\
\hline & Neither agree nor disagree & 40 & 30 & 16 & 19 & 32 & \\
\hline & Strongly disagree / Disagree & 20 & 17 & 21 & 10 & 17 & \\
\hline \multirow{3}{*}{$\begin{array}{l}\text { Improve Land } \\
\text { Use }\end{array}$} & Strongly agree / Agree & 20 & 33 & 26 & 33 & 26 & \multirow{3}{*}{2.93} \\
\hline & Neither agree nor disagree & 45 & 39 & 47 & 43 & 46 & \\
\hline & Strongly disagree / Disagree & 35 & 28 & 26 & 24 & 28 & \\
\hline \multirow{2}{*}{$\begin{array}{l}\text { Urban } \\
\text { Regeneration }\end{array}$} & Strongly agree / Agree & 15 & 13 & 32 & 29 & 19 & \multirow{2}{*}{2.73} \\
\hline & Neither agree nor disagree & 45 & 50 & 37 & 33 & 45 & \\
\hline
\end{tabular}




\begin{tabular}{llllll|l|l|l} 
Strongly disagree / Disagree & 40 & 37 & 32 & 38 & 36 & \\
\hline
\end{tabular}

Base: 118 responses

NB. Percentages may not add up to 100 owing to rounding

The three main reasons as to why a local authority might introduce a WPL were to 'reduce congestion' (61\% agree/strongly agree), 'raise revenue to fund transport improvements' (53\%) and for 'environmental reasons' (51\%). Individual authorities however, placed greater emphasis on specific aspects. For example County Council respondents are more likely to introduce a WPL to 'reduce congestion' whilst urban authorities are more likely to introduce a WPL to achieve 'environmental benefits'.

Similarly, the more urbanised the more likely an authority would introduce a WPL to 'improve land use' and/or 'regenerate the area', though overall 'improving land use' (26\% agree/strongly agree) and 'urban regeneration' (19\%) are the least primary reasons for introducing a WPL. Finally, a greater proportion of Officers agree/strongly agree that a WPL would be introduced in order to 'reduce congestion' or 'raise revenue' whilst a greater proportion of Councillors believe that a WPL would be introduced for 'environmental reasons' or to 'regenerate the urban area'.

\section{Principles of a WPL}

The survey sought to identify the views of respondents with respect to the principles of a WPL. This included the hypothecation of the revenue for local transport purposes; whether employers should be responsible for funding local transport as the WPL implies; and if employers should pay the full cost of the levy or pass the charge on to their employees. See Figure 3.

\section{Figure 3. Type of authority: Principles of a WPL}

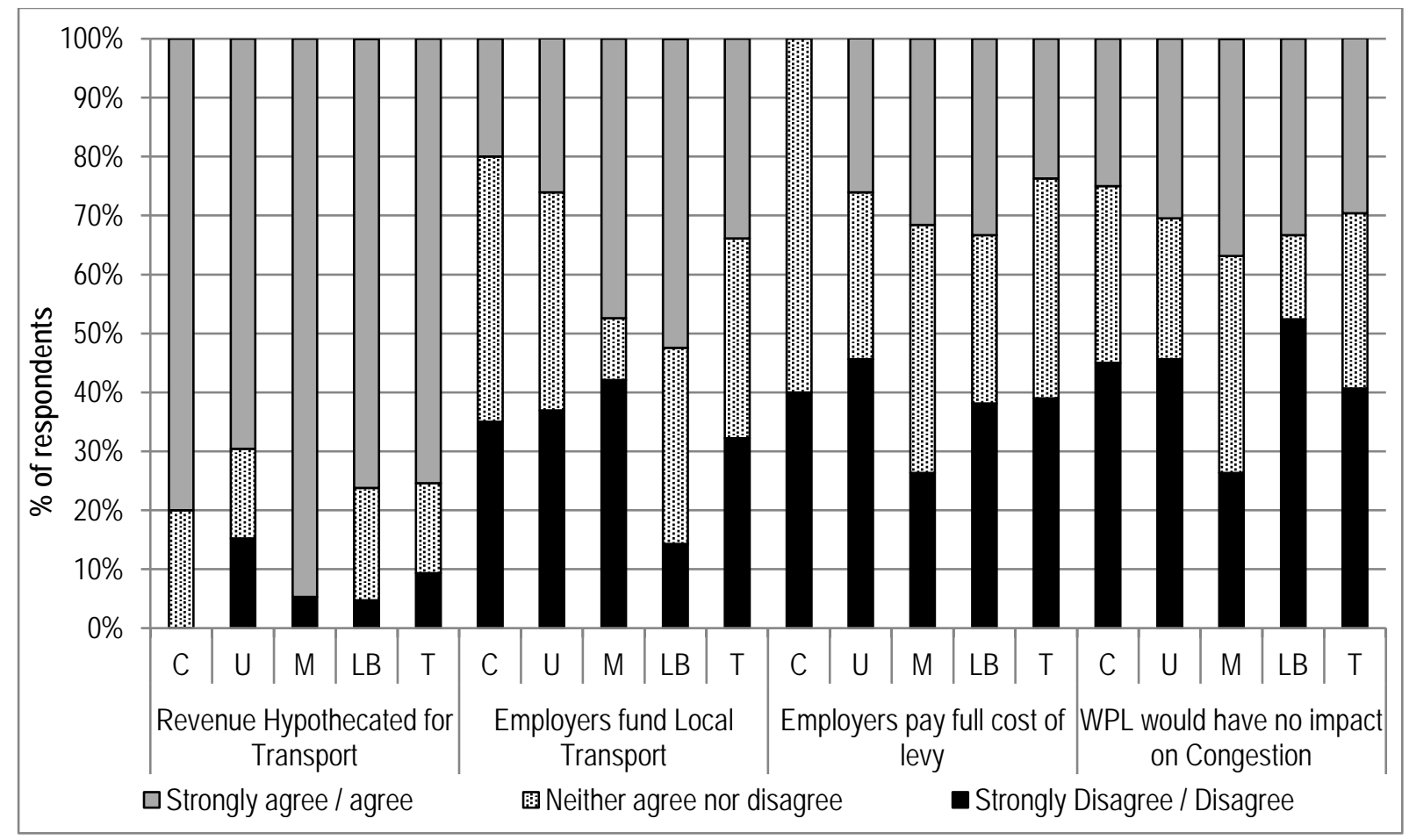

Base: 118 responses 
Three-quarters of the respondents were in agreement that the revenue should be 'ring fenced to be spent on improving local transport' and this was consistent across all authority types. By contrast, only 34\% agreed/strongly agreed that 'employers should fund local transport', with County Councils being the least convinced (20\%), though the view of the respondents from London Boroughs was the extreme opposite, where only 14\% disagreed. Meanwhile still fewer (24\%) responded that 'employers should pay the full cost of the levy', with no-one from County Councils supporting this idea, with 33\% from London Boroughs agreeing.

\section{Issues associated with introducing a WPL}

The views of the respondents with respect to the issues associated with introducing a WPL related to the need for 'political stability'; 'identifying the number of parking spaces'; 'identifying the boundary' within which the levy would apply; the 'cost of implementation'; 'equity' of the scheme; 'available public transport provision'; and the 'use of the revenue'.

At least two thirds of the respondents from all authorities were either concerned or very concerned with the 'cost of implementation' (74\%), 'equity and fairness of the scheme' (72\%) and the 'lack of public transport provision' as a realistic alternative to car use (75\%). Furthermore, the majority of the respondents viewed 'identifying the boundary' for the area that is affected by the charge (59\%) as well as 'how to use the revenue' from a WPL (64\%) as further concerns. Respondents from London Boroughs were the least concerned (57\%) with the 'availability of public transport' as an alternative to motoring. Moreover, it was found that the more rural the authority the more concerned the respondent was likely to be with regard to 'availability of public transport'. London Boroughs were the least concerned (48\%) and Metropolitan areas the most concerned (84\%) with respect to 'how to use the revenue'.

Only 39\% of the respondents highlighted a 'lack of political stability' as an issue although the views varied significantly between the different types of authority. This is because $55 \%$ of respondents from County Councils, compared to 15\% in London Boroughs, agreed that a 'lack of political stability' would be a concern for introducing a WPL. The results highlighted that the more urban the authority, the less of an issue political stability seemed to be.

Establishing the number of employer parking spaces was not perceived to be a significant problem, as $47 \%$ of respondents stated disagree or strongly disagree that the number of spaces would be an issue. London Boroughs perceived it as the greatest problem (38\%) and County Councils the least (15\%).

\section{Issues following the introduction of a WPL}

If a WPL were to be introduced, then potential concerns related to business compliance; enforcement; impact on new and existing businesses; displaced parking; and the short and longterm impact of such a scheme.

The greatest concern following the introduction of a WPL were with respect to 'impact on new business' (82\% concerned or very concerned), the 'impact on the area in the short term' (81\%), 'impact on existing business' (79\%), 'business compliance' (77\%), 'enforcement' (76\%), 'displaced parking' (76\%) and the 'impact on the area in the long term' (74\%).

The area of most concern was for the 'impact on new businesses', particularly for County and Metropolitan Councils (90\%). Another observation was that the more rural the type of authority the more concerned they were likely to be with respect to the 'enforcement' of the scheme. The final point is that there is slightly greater concern for the impact on the area in the 'short term' 
(81\%) compared to the 'long term' (74\%). Whilst the difference is minimal, it does indicate that fears for adopting a WPL centre more on the immediate aftermath of its introduction than on its continued operation later on.

Influence of existing schemes on future WPL's

As regards the future, it was felt to be important that the influence of schemes already in existence would impact on the attractiveness of the measure as well as the support local authorities would receive if they introduced their own scheme based on locations already with a parking levy.

In the event, only 7\% of respondents agreed that the introduction of the WPL in Nottingham (the first in the UK) had made their authority more inclined to introduce such a scheme, though a significantly larger proportion (44\%) agreed that if a WPL was introduced in other locations they would be more inclined to do so.

In more detail, respondents from London Boroughs were most likely to agree (52\%) that the attractiveness of a WPL would be increased if introduced elsewhere; this was closely followed by County Councils (50\%), then Unitary (46\%) and Metropolitan Councils (42\%). Furthermore, the more rural the type of authority the more likely they were to disagree that the introduction of a WPL in Nottingham would make them more inclined to introduce their own WPL. Thus $60 \%$ of County Council respondents disagreed compared to only $29 \%$ from London Boroughs.

With respect to support, only 5\% of the respondents stated they would not seek support from local authorities with an existing WPL in the UK if they were to introduce their own scheme. Of these, there is little difference between the different types of Council with approximately $80 \%$ of all authorities stating agree or strongly agree. A significantly larger proportion of the respondents (41\%) stated they would not seek support from local authorities with a WPL from overseas. Here however, Metropolitan areas (47\%) and London Boroughs (33\%) being most likely to do so in comparison to Unitary Authorities (26\%) and County Councils (25\%).

\section{Likelihood of another local authority introducing a WPL in the UK}

As to the likelihood of additional schemes being implemented in the UK overall less than a fifth of the respondents (21 out of the 118) had previously considered introducing a WPL in their locality. There was a similar level of interest from County Councils, Unitary Authorities and London Boroughs (about 20\%), with Metropolitan Districts the least likely (11\%) to have considered such a scheme. Interestingly ten respondents stated agree or strongly agree that their authority would introduce a WPL in the next five years and 21 respondents stated they would introduce a scheme within the next ten years.

Despite the issues raised, County Councils (20\%) were the most likely to agree that they would introduce a WPL in the next five to ten years. Whilst London Boroughs were the least likely to agree (15\%), 48\% stated neither agree nor disagree which provides an indication that these respondents are not ruling out the possibility of introducing such a scheme. Respondents from Metropolitan Areas were the type of authority most likely to agree that they would 'never introduce a WPL', although only marginally more when compared to the other authorities. Moreover, 36\% of respondents stated neither agree nor disagree for introducing a WPL in 10 years whilst 31\% stated they would 'never introduce a WPL'. An indication as to the reasons why some authorities have no interest in a WPL, was provided in the 'any other comments' section of the survey. 
"During a time of a struggling economy, [a] WPL is the last thing that any Local Authority would introduce, especially given the priorities of Local and National Government to regenerate and boost economies."

“There is an extreme 'nervousness' about using tariffs to influence commuter behaviours in Greater Manchester following the [failed] Congestion Charging referendum."

\section{DISCUSSION}

There is a pressing need to reduce car dependency and hence traffic congestion and levels of air pollution in cities worldwide. Although parking policies can be used to achieve multiple objectives (Marsden 2006, Qian et al 2011 and Pierce and Shoup 2013), a lack of control over private non-residential parking, particularly at the workplace, reduces the effectiveness of such policies. To correct this, the UK Government enacted legislation in 2000 to allow local authorities to introduce a WPL. It was anticipated that the Act would lead to multiple schemes being introduced across the country. However, to date, only one WPL has been introduced. This paper has focused on the possible reasons for the low uptake and the potential likelihood of future schemes being introduced in the UK.

First, parking policies, and more specifically increasing the cost and reducing the supply of parking, were generally viewed by UK transport policy makers to be ineffective and unacceptable measures for reducing congestion. The exception being that two-thirds of respondents from London Boroughs viewed a WPL as being both acceptable and effective. This however was thought to be because these respondents also identified the seriousness of the issues associated with congestion and air pollution, which can be seen to be the result of the unique circumstances facing London (Burchell et al. 2015).

Second, whilst $75 \%$ of the respondents supported the principle that the revenue should be hypothecated to fund local transport which can improve the equity of the scheme (Pierce and Shoup 2013), only 32\% of respondents believe employers should fund local transport and only $24 \%$ believe employers should pay the full cost of the levy. Once more, however, the London Boroughs differed in their response. This is because these respondents were more in agreement that employers should fund local transport which provides an indication as to why these respondents were more likely to view a WPL as more effective and acceptable.

Third, at least $70 \%$ of respondents were concerned or very concerned with the cost of implementation, compliance, equity, enforcement, displaced parking, impact on business as well as the impact on the area in the short term and long term if a WPL was introduced. These concerns could mean local authorities are reluctant to introduce such a measure. Specifically, rural locations were more concerned than urban locations. For example, County Council respondents were more concerned with political stability. In contrast, political stability was less of a concern for London Boroughs and this could be because the council boundaries are narrower which mean people are more likely to commute from another jurisdiction and therefore having no voting power in the constituency they work in. This could indicate a WPL is more likely to be introduced in areas with smaller administrative areas and narrower boundaries.

Despite these issues, ten respondents stated that their authorities would consider introducing a WPL in the next five years and 23 respondents in the next ten years, primarily to reduce congestion, for environmental reasons and (to slightly lesser extent) to raise revenue. On this 
basis, it is likely that a limited number of other authorities are likely to introduce a WPL in the short to medium term following the introduction of the WPL in Nottingham. Furthermore, although less than $10 \%$ of the respondents thought the Nottingham WPL had made the scheme more attractive, just under half of the respondents would view the WPL as more attractive if it was also introduced elsewhere. This would suggest that if the new WPL schemes materialise in the next ten years then further schemes could be expected.

If additional schemes are introduced, more than $80 \%$ of the respondents stated they would seek support in introducing a WPL from local authorities in the UK that have already implemented such a scheme, but only 30\% would seek help/advice from foreign locations. This indicates the preference to learn lessons from locations with similar contextual circumstances and therefore highlights the importance of 'first mover' authorities on a national level when new policies are being adopted. This lesson is of particular importance and reflects experience in Australia, where following the introduction of a parking levy in Sydney, three other cities introduced have their own scheme. Indeed, if this experience is repeated in the UK, as suggested by the respondents, one might argue that the decision of NCC to introduce a WPL could have an impact far beyond the boundaries of the Nottingham scheme and help address the issues associated with peak period congestion caused by free workplace parking in cities across the country as additional WPL’s are implemented.

With reference to the final point it is interesting to note that since the survey was undertaken, a number of UK local authorities have begun, albeit somewhat tentatively, to consider the possibility of introducing a WPL. For example, in Scotland it is understood that the City of Edinburgh Council and Glasgow City Council would welcome the Scottish Government affording councils the power to introduce a workplace car parking levy and, in London, it is understood that a consultation is underway within the London Borough of Hounslow as to a proposed hypothecated workplace parking levy. The London Borough of Brent is also reportedly looking into the feasibility of a workplace parking levy. In addition, Reading Borough Council is thought to be exploring the possibility of a workplace parking levy closely based on Nottingham's scheme while Bristol City Council is reportedly considering implementing either a workplace parking levy or a congestion charge as potential ways to raise funding for local transport projects.

\section{CONCLUSION}

Rising levels of urbanisation combined with the urgent need to reduce private vehicle dependency and invest in sustainable public transport alternatives to the private car has prompted Governments around the world to introduce a range of legislative interventions that seek to manage demand for car parking spaces by managing demand and/or introducing a levy for certain types of parking. The City of Nottingham in the UK was the first and, to date, only urban area in the UK to introduce a WPL. The reasons for this are complex and offer important lessons for other urban transport authorities worldwide. One important condition underpinning the implementation of any WPL is public acceptance of such a measure as, without it, the political will necessary to enact the intervention will not be forthcoming. Our findings have indicated that local authorities remain concerned at the perceived low levels of public acceptability. However, given the prominence of environmental issues on both global and local political agendas, it is likely that public pressure to actively demand manage polluting transport modes will grow and public willingness to travel on alternative modes will increase. The findings of this research have broad implications for policy and practice, as lessons learned from the UK can be used to inform the development of other WPL and parking pricing interventions overseas. 


\section{ACKNOWLEDGEMENTS}

The authors are indebted to Frank Witlox and two anonymous referees for their detailed comments on earlier drafts of the paper. Their insights and suggestions made for a much improved and focused paper.

\section{REFERENCES}

Acts of Parliament. 2000. Transport Act 2000 c. 38. London: HMSO

Bonsall, P.W. and Milne, D.S. 2003. Urban road user charging and workplace parking levies. In: Preston, J. and Hine, J. ed. Integrated Futures and Transport Choices. Ashgate. 259-286

Bryman, A. 2004. Social Research Methods. Second Edition. Oxford: Oxford University Press.

Burchell, J., Ison, S.G., and Enoch, M. E., 2015. The Smeed Report Fifty Years On: A Role for the Workplace Parking Levy? Transportation Planning and Technology, 38(1), 62-77.

Chester, M., Horvath, A., and Madanat, S. 2011. Parking Infrastructure and the Environment. Access, 39: 28-33

Dale, S., Frost, M., Ison, S.G., Quddus, M.A and Warren, P, 2017. Evaluating the Impact of a Workplace Parking Levy on Local Traffic Congestion: The Case of Nottingham, UK, Transport Policy, 59, 153-164.

DETR (Department for Environment, Transport and the Regions). 1998. A New Deal for Transport: Better for Everyone. The Government's White Paper on the Future of Transport. London: DETR

DETR. (2000). Transport Ten Year Plan 2000. London: DETR

Enoch, M., and Ison, S. 2005. Levying charges on private parking: Lessons from existing practice. World Transport Policy \& Practice, 12(1), 5-14.

Forinash, C., Millard-Ball, A., Tumlin, J., and Dougherty, C. 2004. Smart Growth Alternatives to Minimum Parking Requirements. Paper presented at Transportation Research Board Annual Meeting, Washington, DC, January 2004

Hamer, P., Currie, G., and Young, W. 2011. Parking Price Policies - A review of the Melbourne congestion levy. Australasian Transport Research Forum, Proceedings 28 - 30 September 2011. Adelaide: Australia

Higgins, T. J., 1994. Congestion Pricing: Implication Considerations', Transportation Quarterly, 48, 287-298.

Hill, J. 2005. Car park designers’ handbook. Thomas Telford Ltd, London.

HMSO (Her Majesty's Stationery Office). 1996. Transport: The Way Forward - The Government's Response to the Transport Debate. London: HMSO Cm3950 
IHT (Institute of Highways and Transportation). 2005. Parking Strategies and Management. Institution of Highways and Transportation, HQ Media Services, Essex 361.

Ison, S.G., 2000. Local authority and academic attitudes to urban road pricing: a UK perspective, Transport Policy, 7(4), 269-277.

Ison, S.G. and Wall, S, 2002. Attitudes to traffic-related issues in urban areas of the UK and the role of workplace parking charges, Journal of Transport Geography, 10(1), 21-28

Jones, P.M., 1991. UK public attitudes to urban traffic problems and possible countermeasures: a poll of polls, Environment and Planning C: Government and Policy, 9, 245-256.

Jones, P.M., 1998. Urban road pricing: public acceptability and barriers to implementation, Chapter 12 in Button, K.J. and Verhoef, E.T. (eds), Road Pricing, Traffic Congestion and the Environment, Cheltenham: Edward Elgar.

Schade, J., and Schlag, B., 2003. Acceptability of urban transport pricing strategies, Transportation Research Part F, 6, 45-61.

Marsden, G. 2006. The evidence base for parking policies—a review. Transport Policy, 13(6), 447-457.

MYB (Municipal Year Book). 2013. MYB. London: Hemming Group

Pierce, G. and Shoup, D. 2013. Getting the prices right. Journal of the American Planning Association, 79:1, 67-81

Qian, Z. (Sean), Xiao, F. (Evan), \& Zhang, H. 2011. The economics of parking provision for the morning commute. Transportation Research Part A: Policy and Practice, 45(9), 861-879.

RAC (Royal Automobile Club) Foundation. 2012. Spaced Out: Perspectives on Parking Policy

Shoup, D. 2005. The high cost of free parking. American Planning Association. Chicago, Illinois.

SMMT (The Society of Motor Manufactures and Traders), 2014. New Car $\mathrm{CO}_{2}$ Report 2014: The $13^{\text {th }}$ Report. SMMT: London

Thorpe, N., Hill, P.J., and Jaensirisak, S., 2000, Public Acceptance of Travel Demand Management Measures: A Comparative Study, Transport Policy, 7, 242-257.

Transport for NSW. 2013. Parking Space Levy [Online] Available at: http://www.transport.nsw.gov.au (Accessed - 17/03/2017). NSW: Sydney

Vanoutrive, T, Van De Vijver, E, Van Malderen, L, Jourquin, B, Thomas, I, Verhetsel, A and Witlox, F. (2012) What determines carpooling to workplaces in Belgium: location, organisation, or promotion? Journal of Transport Geography, 22, 77-86. 


\section{Appendix}

Local Authority Perspectives with respect to Urban Transport related Issues

Page 2 of 6

Transport in your Locality

1. How would you regard the seriousness of each of the following transport-related issues within your Local Authority area?

\begin{tabular}{|c|c|c|c|c|c|}
\hline & Not at all serious & Not very serious & Fairly serious & Serious & Very serious \\
\hline a. Morning congestion & 0 & 0 & 0 & 0 & 0 \\
\hline b. Evening congestion & 0 & 0 & 0 & 0 & 0 \\
\hline c. Air pollution related to local transport & 0 & 0 & 0 & O & 0 \\
\hline d. Road wear and tear & 0 & 0 & 0 & 0 & 0 \\
\hline e. Noise & 0 & 0 & 0 & 0 & 0 \\
\hline $\begin{array}{l}\text { f. Social exclusion, such as the number of households without a car, } \\
\text { lack of access to public transport and crime on public transport }\end{array}$ & 0 & 0 & 0 & 0 & 0 \\
\hline
\end{tabular}

Effectiveness and Acceptability

\begin{tabular}{|c|c|c|c|c|c|}
\hline & Very ineffective & $\begin{array}{c}\text { Fairly } \\
\text { ineffective }\end{array}$ & $\begin{array}{l}\text { Neither effective nor } \\
\text { ineffective }\end{array}$ & $\begin{array}{c}\text { Fairly } \\
\text { effective }\end{array}$ & $\begin{array}{c}\text { Very } \\
\text { effective }\end{array}$ \\
\hline a. Improvement in the frequency and reliability of public transport & 0 & 0 & 0 & 0 & 0 \\
\hline b. A reduction in the cost of public transport for passengers & 0 & 0 & 0 & 0 & 0 \\
\hline c. Improvement in local railway services & 0 & 0 & 0 & 0 & 0 \\
\hline d. An increase in parking charges on-street and off-street & 0 & 0 & 0 & 0 & 0 \\
\hline e. A reduction in the number of parking spaces on-street and off-street & 0 & O & O & O & O \\
\hline $\begin{array}{l}\text { f. The implementation of a workplace parking levy as part of a package } \\
\text { of measures (a charge employers pay based on the number of parking } \\
\text { spaces at the workplace for staff) }\end{array}$ & O & O & 0 & O & 0 \\
\hline $\begin{array}{l}\text { 9. The implementation of a road user charging scheme as part of a } \\
\text { package of measures (a charge motorists pay for the use of roads at } \\
\text { certain times) }\end{array}$ & O & O & 0 & O & O \\
\hline h. An improvement in cycle ways and pedestrian routes & 0 & 0 & 0 & 0 & 0 \\
\hline i. An improvement in a park and ride network & O & O & O & O & O \\
\hline j. Selective expansion of the road network & 0 & 0 & 0 & 0 & O \\
\hline k. An encouragement of car sharing & 0 & 0 & 0 & 0 & 0 \\
\hline I. An encouragement of home working & 0 & 0 & 0 & 0 & 0 \\
\hline
\end{tabular}

\begin{tabular}{|c|c|c|c|c|c|}
\hline & Very unimportant & Unimportant & $\begin{array}{l}\text { Neither important nor } \\
\text { unimportant }\end{array}$ & Important & $\begin{array}{c}\text { Very } \\
\text { important }\end{array}$ \\
\hline a. An efficient and reliable road network & 0 & 0 & 0 & 0 & 0 \\
\hline b. Efficient and reliable public transport & 0 & 0 & 0 & 0 & 0 \\
\hline c. Improvements to current public transport & 0 & 0 & 0 & 0 & 0 \\
\hline d. Good access to national road and rail links & 0 & 0 & 0 & 0 & 0 \\
\hline e. Safe and efficient cycling and walking routes & 0 & 0 & 0 & 0 & 0 \\
\hline f. Reliable journey times for all modes & 0 & O & 0 & 0 & O \\
\hline $\begin{array}{l}\text { g. Encouraging travellers to use more sustainable methods for travelling } \\
\text { to work (Public transport, walking, cycling) }\end{array}$ & 0 & 0 & 0 & 0 & 0 \\
\hline
\end{tabular}




\begin{tabular}{|c|c|c|c|c|c|}
\hline & $\begin{array}{c}\text { Very } \\
\text { unacceptable }\end{array}$ & $\begin{array}{c}\text { Fairly } \\
\text { unacceptable }\end{array}$ & $\begin{array}{l}\text { Neither acceptable nor } \\
\text { unacceptable }\end{array}$ & $\begin{array}{c}\text { Fairly } \\
\text { acceptable }\end{array}$ & $\begin{array}{c}\text { Very } \\
\text { acceptable }\end{array}$ \\
\hline a. Improvement in the frequency and reliability of public transport & 0 & 0 & 0 & 0 & 0 \\
\hline b. A reduction in the cost of public transport for passengers & 0 & 0 & 0 & 0 & 0 \\
\hline c. Improvement in local railway services & 0 & 0 & 0 & 0 & 0 \\
\hline d. An increase in parking charges on-street and off-street & 0 & 0 & 0 & 0 & 0 \\
\hline e. A reduction in the number of parking spaces on-street and off-street & 0 & 0 & 0 & 0 & 0 \\
\hline $\begin{array}{l}\text { f. The implementation of a workplace parking levy as part of a package } \\
\text { of measures (a charge employers pay based on the number of parking } \\
\text { spaces at the workplace for staff) }\end{array}$ & 0 & 0 & 0 & 0 & 0 \\
\hline $\begin{array}{l}\text { 9. The implementation of a road user charging scheme as part of a } \\
\text { package of measures (a charge motorists pay for the use of roads at } \\
\text { certain times) }\end{array}$ & O & O & 0 & 0 & 0 \\
\hline h. An improvement in cycle ways and pedestrian routes & 0 & 0 & 0 & 0 & 0 \\
\hline i. An improvement in a park and ride network & 0 & 0 & 0 & 0 & 0 \\
\hline j. Selective expansion of the road network & 0 & 0 & 0 & 0 & 0 \\
\hline k. An encouragement of car sharing & 0 & 0 & 0 & 0 & 0 \\
\hline I. An encouragement of home working & 0 & 0 & 0 & 0 & 0 \\
\hline
\end{tabular}

5. If money was no object, what would be your primary transport scheme or intervention undertaken in order to alleviate congestion in your Local Authority area? (Optional)

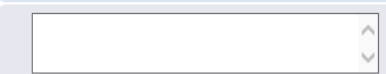

Local Authority Perspectives with respect to Urban Transport related Issues

Introduction of a Workplace Parking Levy

A Workplace Parking Levy (WPL) is a charge employers pay based on the number of staff car parking spaces at the workplace. All of the revenue raised from a WPL is ring-fenced to be spent on improving local transport. Nottingham City Council were the first, and to-date only Local Authority to introduce a WPL in the UK when a charge of 2288 per parking space was placed on employers with 11 or more
parking spaces in April 2012.

6. Has your Local Authority considered introducing a WPL?

Oyes Ono

7. If your Local Authority were to introduce a WPL, would it be introduced primarily...

\begin{tabular}{|l|c|c|c|c|c|}
\cline { 2 - 5 } \multicolumn{1}{c|}{} & Strongly disagree & Disagree & Neither agree nor disagree & Agree & Strongly agree \\
\cline { 2 - 6 } \multicolumn{1}{l|}{ a. to reduce congestion } & 0 & 0 & 0 & 0 & 0 \\
\hline b. to raise revenue to fund transport improvements & 0 & 0 & 0 & 0 \\
\hline c. for environmental reasons & 0 & 0 & 0 & 0 & 0 \\
\hline d. to improve land use & 0 & 0 & 0 & 0 \\
\hline e. to regenerate the area & 0 & 0 & 0 & 0 \\
\hline
\end{tabular}

8. To what extent do you agree with the following

\begin{tabular}{|c|c|c|c|c|c|}
\hline & Strongly disagree & Disagree & Neither agree nor disagree & Agree & Strongly agree \\
\hline $\begin{array}{l}\text { a. A lack of political stability in your Local Authority would be a barrier } \\
\text { to introducing a WWL }\end{array}$ & O & O & o & 0 & 0 \\
\hline $\begin{array}{l}\text { b. Introducing a WPL during the current economic climate would be an } \\
\text { issue }\end{array}$ & 0 & 0 & 0 & 0 & 0 \\
\hline $\begin{array}{l}\text { c. The revenue from the WPL should be ring fenced to be spent on } \\
\text { improving local transport }\end{array}$ & 0 & 0 & 0 & O & 0 \\
\hline d. A lack of understanding of the impact of a WPL would be an issue & 0 & 0 & 0 & 0 & 0 \\
\hline $\begin{array}{l}\text { e. Your Local Authority does not have the resource required to explore } \\
\text { and introduce a WPL }\end{array}$ & 0 & 0 & 0 & 0 & 0 \\
\hline $\begin{array}{l}\text { f. It would be difficult to ascertain how many workplace parking places } \\
\text { exist }\end{array}$ & 0 & 0 & 0 & 0 & 0 \\
\hline g. Local employers should fund local transport improvements & 0 & 0 & 0 & 0 & 0 \\
\hline $\begin{array}{l}\text { h. The employer should pay the full cost of the levy, and not pass it on } \\
\text { to their staff }\end{array}$ & 0 & 0 & 0 & 0 & 0 \\
\hline i. A WPL would not have an impact on congestion & 0 & 0 & 0 & 0 & 0 \\
\hline $\begin{array}{l}\text { j. If other areas introduced a WPL, it would make a WPL in your Local } \\
\text { Authority more attractive }\end{array}$ & 0 & 0 & 0 & 0 & 0 \\
\hline $\begin{array}{l}\text { k. Following the introduction of the WPL in Nottingham, authorities will } \\
\text { be more inclined to introduce a WPL }\end{array}$ & 0 & 0 & 0 & 0 & 0 \\
\hline $\begin{array}{l}\text { 1. If your Authority decided to introduce a WPL, you would seek advice } \\
\text { from Local Authorities with a WPL in the UK }\end{array}$ & O & 0 & O & 0 & 0 \\
\hline $\begin{array}{l}\text { m. If your Authority decided to introduce a WPL, you would seek advice } \\
\text { from Authorities with a WPL from overseas }\end{array}$ & 0 & 0 & 0 & 0 & 0 \\
\hline
\end{tabular}




\begin{tabular}{|c|c|c|c|}
\hline & No exemption & Partial Exemption & Full Exemption \\
\hline a. Schools, colleges and universities & 0 & 0 & 0 \\
\hline b. Hospitals & 0 & 0 & 0 \\
\hline c. Other emergency/essential services & 0 & 0 & 0 \\
\hline d. Charitable owned buildings & 0 & 0 & 0 \\
\hline e. Local authority premises & 0 & 0 & 0 \\
\hline f. Employers which promote green travel plans & 0 & 0 & 0 \\
\hline g. Disabled badge holders & 0 & 0 & 0 \\
\hline h. Motorcycles & 0 & 0 & 0 \\
\hline i. Car share (Vehicles with 2+ occupants) & 0 & 0 & 0 \\
\hline j. Low emission vehicles & 0 & 0 & 0 \\
\hline k. First few vehicles parked at a location & 0 & 0 & 0 \\
\hline
\end{tabular}

\begin{tabular}{|c|c|c|c|c|c|}
\hline & $\begin{array}{c}\text { Very } \\
\text { unconcerned }\end{array}$ & $\begin{array}{c}\text { Fairly } \\
\text { unconcerned }\end{array}$ & $\begin{array}{l}\text { Neither concerned nor } \\
\text { unconcerned }\end{array}$ & $\begin{array}{c}\text { Fairly } \\
\text { concerned }\end{array}$ & $\begin{array}{c}\text { Very } \\
\text { concerned }\end{array}$ \\
\hline a. The overall cost of implementing a WPL & O & O & 0 & O & 0 \\
\hline b. Employer compliance with a WPL & 0 & 0 & 0 & 0 & 0 \\
\hline c. Enforcement of a WPL & 0 & 0 & 0 & 0 & 0 \\
\hline d. Equity/fairness of a WPL & 0 & 0 & 0 & 0 & 0 \\
\hline $\begin{array}{l}\text { e. The public transport provision available as a realistic alternative to } \\
\text { car use }\end{array}$ & 0 & 0 & 0 & O & 0 \\
\hline f. How the revenue raised from the WPL would be used & 0 & 0 & 0 & 0 & 0 \\
\hline g. Displaced Parking caused by a WPL & 0 & O & 0 & O & 0 \\
\hline $\begin{array}{l}\text { h. Identifying the boundary where a WPL charge would apply within } \\
\text { your Local Authority }\end{array}$ & 0 & 0 & 0 & 0 & 0 \\
\hline $\begin{array}{l}\text { i. The impact on the number of new businesses moving in to your } \\
\text { locality }\end{array}$ & 0 & O & 0 & O & 0 \\
\hline j. The impact on existing businesses remaining in your locality & 0 & 0 & 0 & 0 & 0 \\
\hline k. The short term impact of introducing a WPL & 0 & 0 & 0 & 0 & 0 \\
\hline I. The long term impact of introducing a WPL & 0 & 0 & 0 & 0 & 0 \\
\hline
\end{tabular}

Local Authority Perspectives with respect to Urban Transport related Issues

The WPL Charge

Page 4 of

11. How much do you believe the annual cost of the WPL per parking space would need to be to achieve a significant reduction (more than $10 \%$ ) in current workplace parking provision?

OLess than $£ 200 \bigcirc_{£ 201-400} \bigcirc_{£ 401-600} \bigcirc_{£ 601-800} \bigcirc_{£ 801-1000} \bigcirc_{£ 1001}$ or over



13. Do you think your Local Authority is likely to consider introducing a WPL in the next...

\begin{tabular}{|l|c|c|c|c|c|}
\cline { 2 - 5 } \multicolumn{1}{c|}{} & \multicolumn{3}{c|}{} \\
\cline { 2 - 6 } \multicolumn{1}{c|}{ Strongly disagree } & Disagree & Neither agree nor disagree & Agree & Strongly agree \\
\hline a. Five years & 0 & 0 & 0 & 0 & 0 \\
\hline b. Ten years & 0 & 0 & 0 & 0 \\
\hline c. Never & 0 & 0 & 0 & 0 & 0 \\
\hline
\end{tabular}

